\title{
水力発電所の設備とその維持管理の最新動向
}

\author{
正 員 美濃 由明* 正 員 本田 誠司* \\ 非会員 中澤 紳浩*
}

\section{Recent Trends of Hydroelectric Power Plant Equipment and Maintenance}

Yoshiaki Mino*, Member, Seiji Honda*, Member, Nobuhiro Nakazawa*, Non-member

The equipment of hydroelectric power plants has been improving typically by using digital technology and eliminating oil for lubrication and control. According to the investigation executed by the committee of IEEJ, a fault/trouble happened in one equipment in a hydroelectric power plant has decreased to less than once in 5 years due to such improvement and advancement of design and manufacturing technologies. As for maintenance, changing to the condition based maintenance from the time based maintenance has been in progress. Developing diagnostic technologies and the analysis of operating data to understand the condition of the equipment are important.

キーワード：水力発電所，設備改善，設備障害，保全技術

Keywords: hydroelectric power plant, equipment improvement, faults/troubles, maintenance technologies

\section{1. はじめに}

水力発電は, $\mathrm{CO}_{2}$ を発生しない自然エネルギーとして電 力供給に寄与するとともに, 出力制御の容易性から, 周波 数調整など電力系統運用になくてはならない発電所として, 日々の電力供給に重要な役割を果たしている。

水力発電設備（ダムなどの土木設備を除く）は，水車発 電機のような大型電気機器と駆動源となる圧油装置などの 補機および制御装置など, 多様な機器で構成されているが, 近年のディジタル技術の急速な発展や油圧操作機構の電動 化の進展などにより, 機器の構成が変化してきている。

一方, 電力自由化に伴い, 電力会社では, 水力発電所運 転品質の維持向上とともに，価格競争力の強化に向けて発 電コストの削減が進められてきた。その中で, 機器の保全 に関しては, TBM (Time Based Maintenance) から CBM (Condition Based Maintenance) への移行が図られるなど, 保全に対する考え方や保全内容が見直されてきている。

このような状況の下, 水力発電設備の設備障害発生状況 を調査し，今後の更なる保全の最適化に資することを目的 として，2005 年 10 月に「水力発電所の設備障害調査専門 委員会」が立ち上げられ, 2008 年 3 月まで約 2 年半に亘っ て，1995 年度から 2004 年度までの 10 年間を対象に調査 分析が行われた。ここではその調査分析結果を中心に，水

\footnotetext{
* 関西電力 (株) 電力システム技術センター

干 530-6691 大阪市北区中之島 6 丁目 2-27

Power System Engineering Center, The Kansai Electric Power Co., Inc. 2-27, Nakanoshima, 6-chome, Kita-ku, Osaka 530-6691
}

力発電設備やその維持管理の最近の動向について述べる。

\section{2. 水力発電設備の動向}

$\langle\mathbf{2} \cdot \mathbf{1}\rangle$ 設 備 数 今回調査対象とした電力 10 社（電 力 9 社および電源開発 (株)）が保有している水力発電所 は, 2004 年度末で 1,217 箇所, 合計出力は $42,345 \mathrm{MW}$ で あり, 出力では発電設備の約 $20 \%$ 占めている ${ }^{(1)}$ 。発電機 台数は 1,839 台で, 発電所一箇所当たりの発電機台数は平 均 1.5 台, 単機出力が大きい揚水式を除く発電機 1 台当た りの平均出力は $10 \mathrm{MW}$ である。水力発電所には, 揚水式 (電力需要の少ない夜間に上池に水を上げ, 電力需要の大き い昼間にその水で発電する方式), 貯水池式 (発電量を季節 的に調整可能な大容量貯水池を持つもの), 自流式 (流れ込 み式および調整池式) 発電所があるが, それらの比率は図 1 の通りである。

発電所数では流れ込み式と調整池式が $92 \%$ と多いが, 出

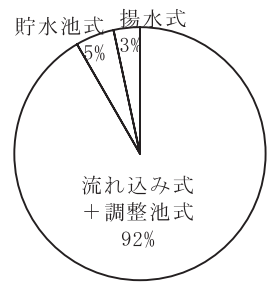

(a) 発電所数

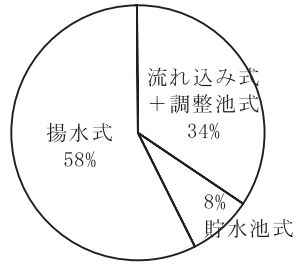

(b) 出力 (a) Number of power station

図 1 水力発電所の方式別比率

Fig. 1. Classification of hydroelectric power station. 
力では単機出力の大きい揚水式が半分以上を占めている。

今回調査した 1995 年度から 2004 年度の 10 年間では, 発 電所の譲渡・取得や建設・廃止などにより 3 発電所, $763 \mathrm{MW}$ が増加していた。

\section{$\langle\mathbf{2} \cdot \mathbf{2}\rangle$ 設備の変化}

（1）設備の簡素化 水力発電所では，保守性・信頼 性の向上，オイルレス化などを目的として，設備の簡素化 が進められている。表 1 に簡素化の進められている設備と その減少数を示す。グリース給油装置を除くと, 設備数に かかわらず設備減少数に大きな差はない。これは，古い発 電所の改修時にこれらの設備がセットで簡素化されている ためと推定される。

表 1 設備の省略

Table 1. Simplification of the equipment.

\begin{tabular}{|c|c|c|}
\hline & $\begin{array}{c}1995 \text { 年 } \rightarrow 2004 \text { 年 } \\
\text { での減少数 }\end{array}$ & $\begin{array}{c}2004 \text { 年度末 } \\
\text { 設備数 }\end{array}$ \\
\hline 給水装置 & 66 台 & 1,678 台 \\
\hline 圧油装置 & 68 台 & 1,339 台 \\
\hline 空気圧縮装置 & 55 台 & 782 台 \\
\hline 潤滑油装置 & 57 台 & 716 台 \\
\hline 制 圧 機 & 56 台 & 426 台 \\
\hline グリース給油装置 & 80 台 & 161 台 \\
\hline
\end{tabular}

（2）設備形態の変化設備の簡素化と同様に，保守 性・信頼性の向上，オイルレス化などを目的として，入口 弁，調速装置（アクチュエータ）では油圧操作からの電動 化が，励磁制御装置，自動運転制御装置，調速装置（レギュ レータ）ではディジタル化が，励磁装置ではブラシレス化 が進められている。表 2 にその進展状況を示す。電動化, デイジタル化とも 1980 年から始まっており，約 25 年かけ て，電動化で $20 \%$ 強まで，ディジタル化で $25 \%$ 程度まで進 んできたことになる。

表 2 設備形態の変化

Table 2. Change of the equipment.

\begin{tabular}{|c|c|c|c|c|}
\hline & 1995 年度末 & 2004 年度末 & $\begin{array}{l}2004 \text { 年度末 } \\
\text { 設備数 }\end{array}$ \\
\hline \multirow{2}{*}{$\begin{array}{l}\text { 電 } \\
\text { 動 } \\
\text { 华 } \\
\text { 率 }\end{array}$} & 入口弁 & $19 \%$ & $25 \%$ & 1,542 台 \\
\hline & $\begin{array}{l}\text { 調速装置 } \\
\text { (アクチュエータ) }\end{array}$ & $15 \%$ & $22 \%$ & 1,834 台 \\
\hline \multirow{3}{*}{$\begin{array}{l}\text { デ } \\
1 \\
\text { 棌 } \\
\text { 兄 } \\
\text { 华 }\end{array}$} & 励磁装置 & $11 \%$ & $21 \%$ & 1,821 台 \\
\hline & $\begin{array}{l}\text { 自動運転 } \\
\text { 制御装置 }\end{array}$ & $21 \%$ & $26 \%$ & 1,807 台 \\
\hline & $\begin{array}{l}\text { 調速装置 } \\
(\text { レキュュータ) }\end{array}$ & $18 \%$ & $31 \%$ & 1,819 台 \\
\hline \multicolumn{2}{|c|}{ 励磁装置のブラシレス化率 } & $40 \%$ & $46 \%$ & 1,801 台 \\
\hline
\end{tabular}

\section{3. 水力発電所設備障害の発生動向}

$\langle\mathbf{3} \cdot \mathbf{1}\rangle$ 設備障害発生件数 水力発電所機器の 1 台 1 年当たりでの障害発生件数を図 2 に示す。今回調査したの は 1995 年度から 2004 年度の 10 年間であるが，同様の調

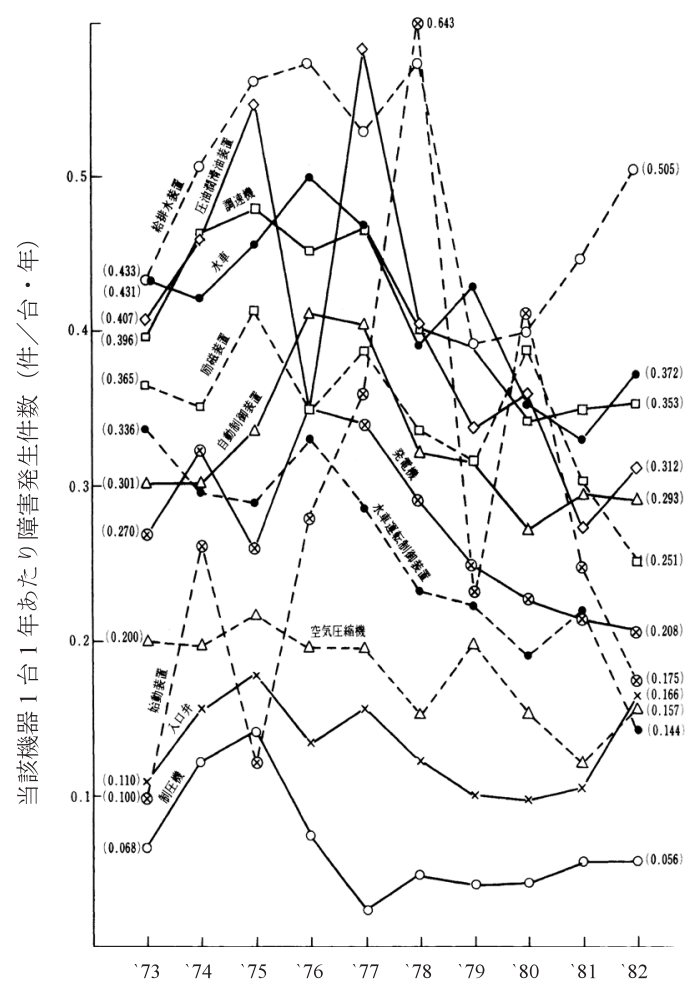

(a) 1973-1982 年度の設備障害発生件数 (2)

(a) Number of troubles happened from 1973 to 1982

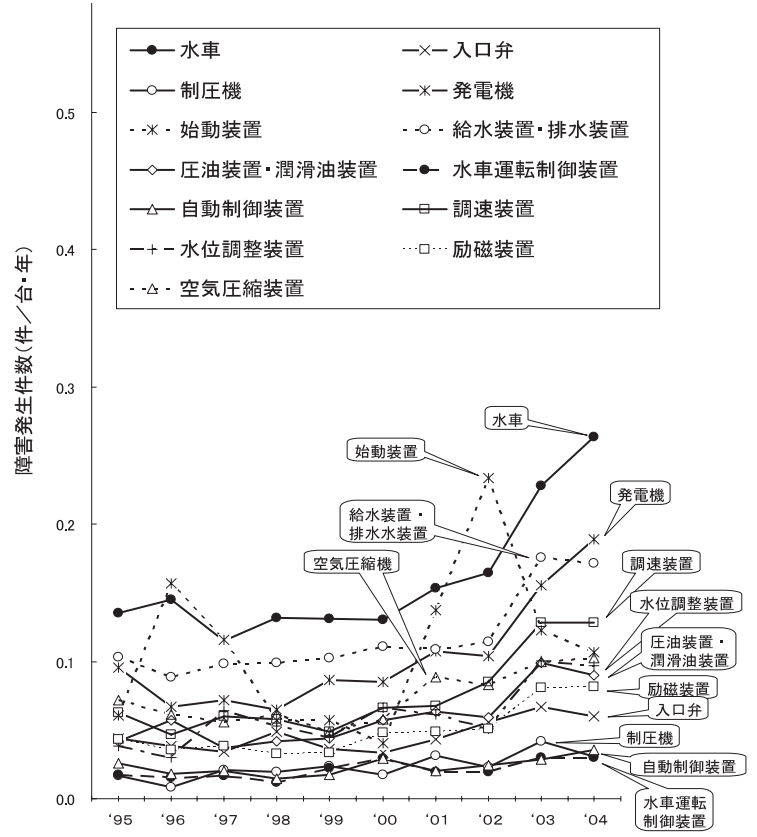

(b) 1995-2004 年度の設備障害発生件数

(b) Number of troubles happened from 1995 to 2004

図 2 年度別, 機器 1 台 1 年あたりの障害発生件数

Fig. 2. Number of troubles per unit-year. 
査は 1973 年度から 1982 年度の 10 年間でも行われており, 図 2 には，その結果も合わせて示している。

今回の調査結果から, 機器 1 台 1 年当たりの障害発生件 数は，多いものでも概ね 0.2 以下（5 年に 1 回以下）であ り, 前回調查の 1970 年代と比べて大幅に減少している。前 章で述べた設備の簡素化や設備形態の恋化も含めて，老朽 設備の改修が進んだことや，機器の製作施工技術が進歩し たことなどが寄与していると考えられる。

図 2 から, 他の部位より障害発生件数が多いのは, 水車, 発電機，給排水装置であることがわかる。障害発生部位を 調べたところ，可動部や流水部での自然劣化，自然現象を 原因とするものが多かった。例えば，水車では，流水中の 異物がつまることによるガイドベーン弱点ピンの折損, 発 電機では，冷却水配管・弁類からの漏水やブレーキの動作 不良などが多い。

また, 2000 年頃から障害発生件数に増加傾向が見られる。 増加しているのは，さしあたり運転には支障がなく次回点 検時に処置すればよいと判断される軽微な障害で，IT 化の 進展により，電力会社が保全デー夕の管理を細かく行うよ うになったことや TBM から CBM への移行, 発電所の重 要性や障害発生時の影響度合いを考慮した合理的な保全方 法の指向など，メンテナンスに対する考え方の変化が原因 と考えている。

$\langle\mathbf{3} \cdot \mathbf{2}\rangle$ 設備障害発生原因

図 3 は, 原因別の設備障 害発生率である。発生原因は, 自然劣化, 自然現象が多く, 製作不完全，施工不完全，保守不完全の比率は少ない。一 方, 発生原因でその他, 原因不明の率が多くなっているが, これは, 障害発生が少なくなる中, 発電所固有要因による ものや一過性で再現しないトラブルの比率が増えてきてい るものと推定している。

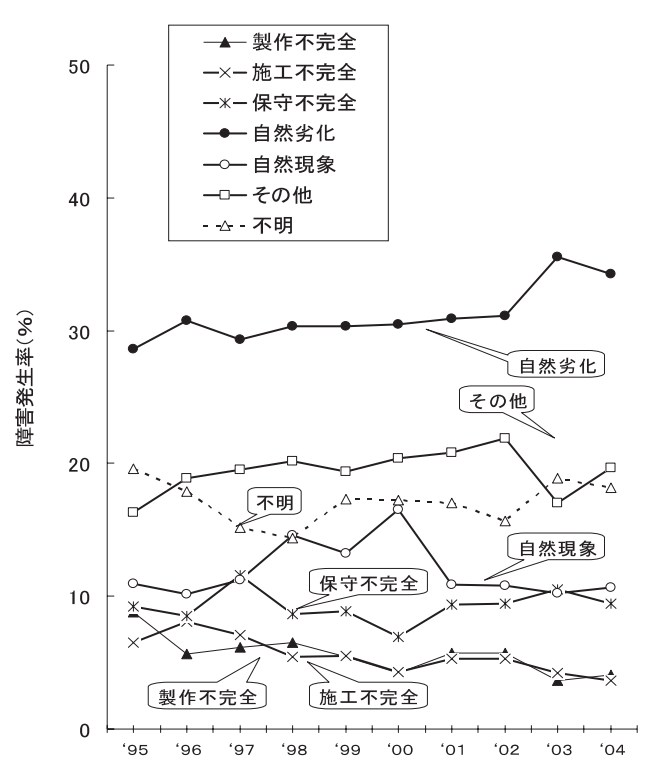

図 3 年度別, 原因別, 障害発生率

Fig. 3. Ratio of causes of troubles.

\section{4. 今後の動向}

$\langle\mathbf{4} \cdot \mathbf{1}\rangle$ 設 備 水力発電設備については, 信頼性 の向上や保全の省力化の観点から, 第 2 章で述べたような 設備の簡素化や電動化, ディジタル化などが今後とも進展 していくと考えられる。これらに加えて, 近年, 樹脂軸受 けの適用が進められている。

軸受けの摺動面には，従来ホワイトメタルが使われてい たが，それに替わる材質として，耐摩耗性，耐焼付性，高 温での機械的強度に優れかつ摺動摩擦係数が低い樹脂が適 用されるようになってきた。樹脂軸受けの採用により損失 の低減, 軸受け空冷化 (冷却水レス) 範囲の拡大, スラス 卜軸受押上装置の省略，ブレーキ開始速度の低下によるブ レーキシューの磨耗と磨耗粉による污損の低減などが図れ るメリットがある。樹脂軸受けの適用は中小水力発電所か ら始まったが, 最近では大容量揚水発電所への適用も進め られている(3) (9)。

$\langle\mathbf{4} \cdot \mathbf{2}\rangle$ 維持管理 第 3 章でも触れたように, 水力発 電所の保全に関しては TBM から $\mathrm{CBM} へ の$ 移行, 発電所 の重要性や障害発生時の影響度合いを考慮した合理的な保 全方法の指向など，コストと信頼性の両立を目指した取り 組みが行われている。そのためには，設備診断技術の開発 や運転保守デー夕に基づく設備状態の把握が大切である。

設備診断技術の例としては，固定子巻線の絶縁診断技術 があげられる。一般に発電機を長時間運転すると, 固定子 コイルは熱的，機械的なストレスを受け絶縁性能が低下し， コイルの絶縁物表面や内部の微小ギャップで部分放電が発 生する。定期点検時（停止中）や運転中にこの部分放電を 検出するため各種の方法が実用化されている。関西電力で は，運転中に簡易に測定できる方法として，図４に示すよ うに固定子スロット内に設置されている測温素子 (RTD) を部分放電検出センサとして活用した，可般式の部分放電 モニ夕を開発し，活用している。図 5 は，実機において部 分放電を検出した例である。コイル修纕前後で比較すると 部分放電レベルは $1 / 100$ 以下に低下している(10)。

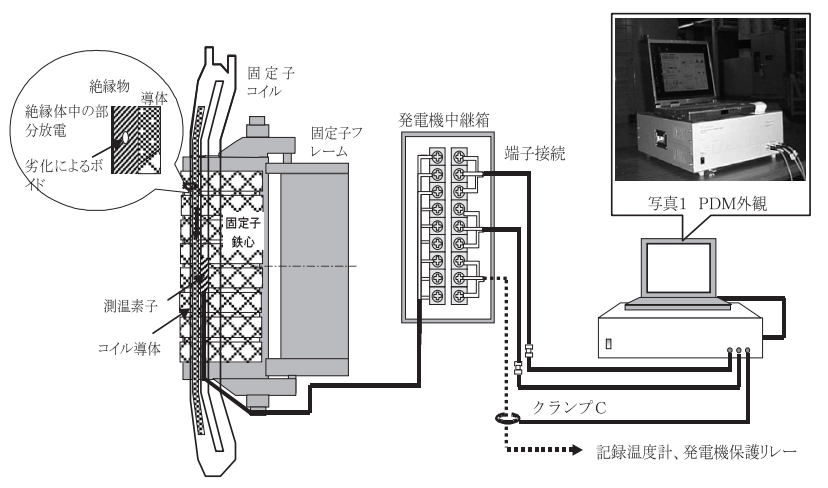

図 4 部分放電モニ夕の基本構成

Fig. 4. Basic configuration of the partial discharge monitor. 


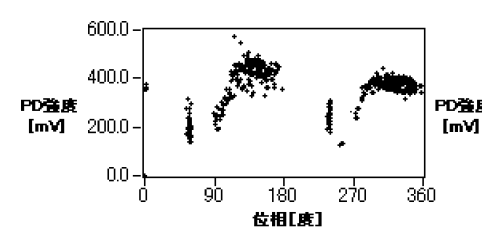

(a) 部分放電有 (コイル修繥前)

(a) Coil with partial discharge (Before repair)

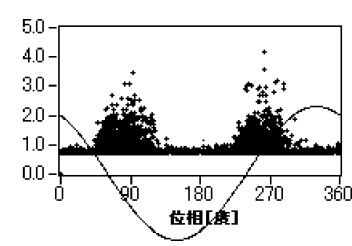

(b) 部分放電無（コイル修繕後）

(b) Coil without partial discharge (After repair)
して，今後益々重要な役割を果たすものと考えており，少 しでも多くの電力を低廉なコストで供給できるよう，今後 とも合理的な設備形成や維持管理手法の開発，実施に努め て行く所存である。

最後になりましたが，調査，研究にご協力頂いた委員会 関係者に深く感謝いたします。

(平成 20 年 4 月 21 日受付)

図 5 コイル修繥前後における部分放電分布

Fig. 5. Partial discharge in stator coils before/after repair.

水力発電所の設計は, 落差や流量など河川の状況により 異なって打り，CBM を実現するためには，発電所每に機器 の状態をできる限り定量的に把握する必要がある。そのた めには，上記のような診断装置だけではなく，日常の運転 保守デー夕の分析が大切である。図 6 は, 関西電力奥多々 良木揚水発電所で測定した, 軸受け温度と冷却水温度との 相関図である。

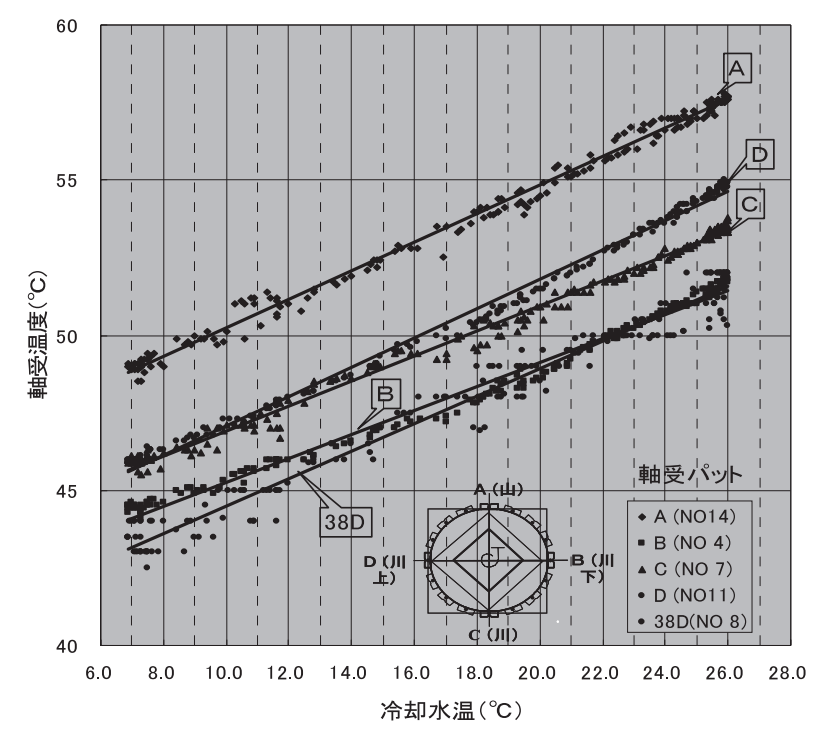

図 6 軸受温度一冷却水温度相関図

Fig. 6. Relation between temperatures of metal and cooling water.

図のように，軸受けパッド毎に軸受け温度と冷却水温度 には強い相関がある。従って，もし相関から外れたデー夕 が出てくれば，何らかの異常が起こっていると判断できる。

この例の他, 季節により水車発電機の基礎が伸縮し, 軸 受ギャップが年周期で変化していることを示すデータなど が得られており，保全管理に大きく貢献している(11)。

\section{5. まとめ}

電気学会「水力発電所の設備障害調査専門委員会」での調 査結果を中心に, 最近の水力発電所設備や維持管理の動向 について述べた。地球温暖化対策が重要課題となる中，水 力発電所は，経済合理性のある貴重な自然エネルギー源と

\section{文献}

（1）電気事業連合会ホームページ：http://www.fepc.or.jp/

（2）「水力発電所の設備障害に関する調査研究」, 電気学会技術報告（II 部), No.246 (1987-4)

（3）「水車発電機用新素材軸受の高性能化」, 東芝レビュー, Vol.53, No.9 (1998-9)

(4)「水車発電機/発電電動機における最新技術」, 三菱電機技報, Vol.74, No.11 (2000-11)

(5)「新素材スラスト軸受の開発と適用」, 電気評論, pp.7-14 (2002-3)

（6）「揚水発電所向け発電電動機への樹脂軸受の初適用」, 東芝レビュー, Vol.58, No.1 (2003-1)

（7）「環境保全, 機器の長寿命化に貢献する水力発電技術」, 東芝レビュー, Vol.58, No.7 (2003-7)

（8）「最新の水力発電技術」, 三菱電機技報, Vol.81, No.10 (2007-10)

（9）「水車・発電機の設備更新における技術動向」,富士電機システムズ, 新エネルギー財団発表

（10）「可搬式発電機部分放電モニターの開発一保全技術の高度化とコス 卜低減—」, R\&D News Kansai (2003-11)

(11）宇野 真・山本茂文・長末史朗：「地下発電所㧍けるガイド軸受への 季節的基礎変位の影響」, 電気学会回転機研資 (2002-10)

美 濃 由 明 (正員) 1959 年 3 月 30 日生。 1983 年 3 月京都 大学大学院電気工学専攻修士課程卒業。同年 4 月

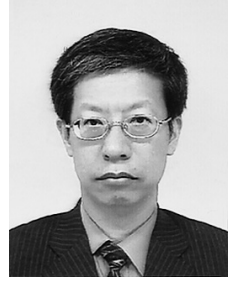
関西電力 (株) 入社。主として, 水力発電所, 変電 所の設計，保全，技術開発に従事。電気学会「水 力発電所の設備障害調査専門委員会」委員長。

本田誠司

（正員） 1960 年 9 月 6 日生。 1981 年 3 月石川工 業高等専門学校電気工学科卒業。同年 4 月関西電 力 (株) 入社。主として水力発電所の設計, 建設, 保全に従事。電気学会「水力発電所の設備障害調 查専門委員会」幹事。

中 澤 紳 浩 (非会員) 1968 年 5 月 16 日生。1 1987 年 3 月滋 賀県立長浜商工高等学校電気科卒業。同年 4 月関 西電力（株）入社。主として水力発電所の設計, 保全に従事。電気学会「水力発電所の設備障害調 査専門委員会」幹事補。 